\author{
Wincenty KULPA ${ }^{1}$ \\ Antoni STASCH ${ }^{2}$
}

\title{
ASSESSMENT OF THE FINANCIAL STANDING OF SELECTED POLISH IT COMPANIES DURING THE COVID-19 PANDEMIC
}

\begin{abstract}
The crisis caused by the COVID-19 pandemic is credited with causing a significant acceleration in digital infrastructure progress. It seems perverse to say that had it not been for the pandemic, IT changes would have taken much longer, even several years. It is predicted that in 2021/22, the pace of IT development will continue to increase, and in the long run, cloud infrastructure will develop dynamically twice as fast. This article presents an analysis of the economic situation and financial standing of the two largest IT companies in Poland, namely, Asseco Poland SA and Comarch SA. The research was been carried out based on the most important business activity ratios: return on assets, return on equity, return on sales, return on investment and the assets and liabilities structure ratios (30) (35). They indicated that Asseco Poland SA has a stronger economic and financial position. The analysis also showed that Asseco is able to develop stably in difficult conditions, as proven by its financial results during the pandemic.
\end{abstract}

Keywords: IT, financial analysis, performance indicators, COVID-19 pandemic.

\section{INTRODUCTION}

The crisis due to the coronavirus pandemic visible in the global economy caused a number of negative effects in the Polish economy. There has been inhibition or even complete stoppage of economic activity in many industries. The crisis caused by the pandemic is attributed to causing a significant acceleration in the progress of IT infrastructure. On the basis of conducted research and an analysis of business involvement in the anti-crisis action strategy of the largest Polish IT companies Asseco Poland SA and Comarch SA, it may be stated that both these IT corporations effectively engaged in offering solutions in the IT market that would enable normal functioning of the Polish economy during the crisis. These companies reported improved financial results and strengthened their position on the capital market not only in Poland.

\footnotetext{
${ }^{1}$ Wincenty Kulpa, PhD, Rzeszow University of Technology, Department of Finance Banking and Accounting (corresponding author). ORCID: 0000-0001-6423-7232.

2 Antoni Stasch, PhD, President of the Scientific Council European Business Club Association e.V, Oedheim. ORCID: 0000-0002-5773-1299.
} 


\section{CHARACTERISTICS OF THE COMPANIES STUDIED}

Two Polish IT companies, Asseco Poland S.A. and Comarch S.A., were selected for the study. Asseco and Comarch are the dominant Polish companies in the IT market in terms of sales of software. Currently, Asseco Poland's market capitalization is over PLN 5.8 billion, while Comarch is valued at PLN 1.8 billion (bankier.pl). The IT industry in Poland is characterized by a diversified market and significant competitiveness. Not only domestic companies operate on this market but also foreign companies mark their presence very strongly. The market analysis data shows that software producers account for the largest share of the IT market in Poland $(38.1 \%)$, followed by IT service providers $(28 \%)$, producers of IT hardware (19\%), and companies operating in the IT infrastructure segment (14.3\%) (pl.asseco.com; brandsit.pl).

Asseco Poland is listed on the Warsaw Stock Exchange with a stake in the following indices: WIG $20-1.76 \%$, WIG - 1,21\%, WIG-INFO - 37.24\%, WIGTECH $-10.01 \%$ (bankier.pl). The company is one of the largest IT companies in Poland and a well-known company abroad, whose business is focused on the sale of proprietary software and services (prnews.pl). It currently employs 22,300 people. Asseco Poland S.A. was ranked first in the Polish IT market category by Computerworld TOP200 in its 2018 report. Figure 1 shows the stock price of Asseco Poland over the period of 2017-2021. It can be seen that between 2018-2019 the stock price has declined somewhat, but since mid-2019 the stock price has shown a steady upward trend. The lowest price was recorded on 22 June 2018, when it was 37.8400 PLN, while the highest price was 75.9000 PLN on 1 June 2020 (www.bankier.pl).

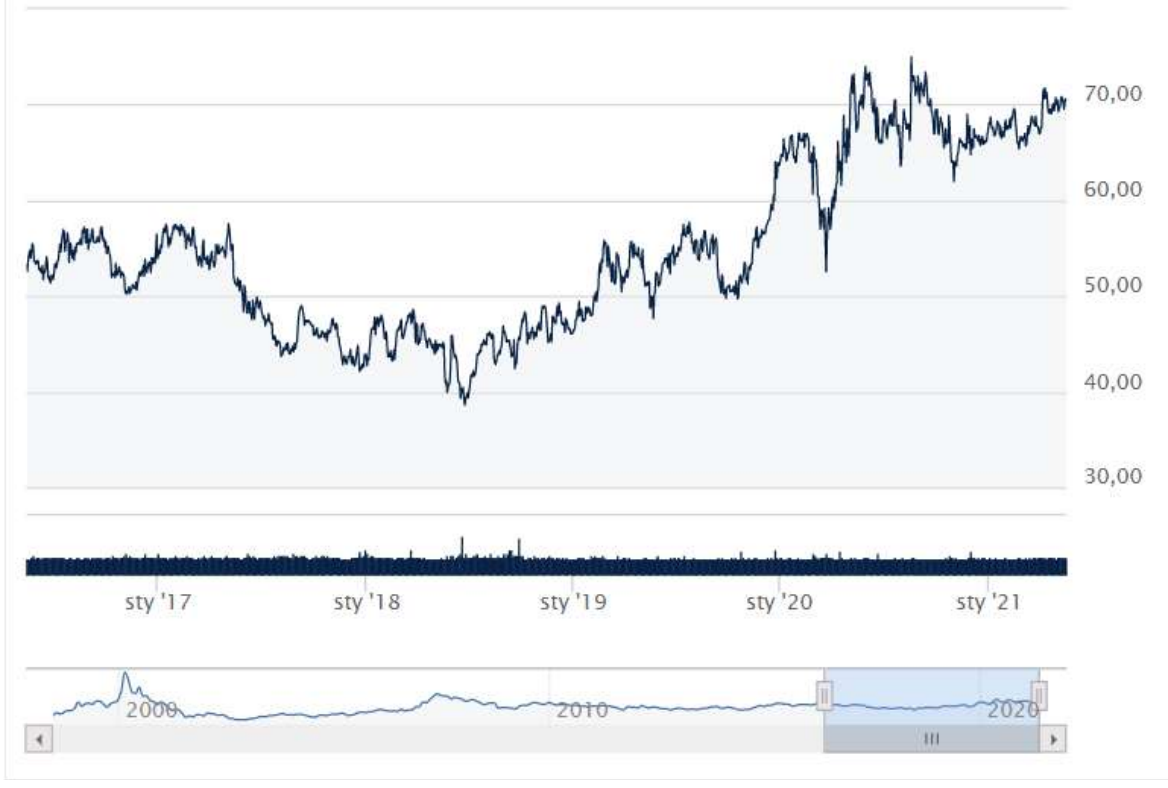

Figure 1. Quotes of Asseco Poland on the Warsaw Stock Exchange in the period 2017-2021 Source: (bankier.pl/inwestowanie/profile/quote.html?symbol=ASSECOPOL). 
The largest competitor of Asseco Poland is Comarch S.A., which is considered a smart computer company. Founded in 1993 in Cracow, it is engaged primarily in the supply of software and IT services. Comarch is a capital group having its divisions in Europe, Asia, South America and North America. The group consists of, among others: Comarch Software AG, based in Dresden and Frankfurt am Main, and Comarch Inc. based in the USA. It currently employs 6500 people (bankier.pl).

On 4 April 2017, Comarch became the owner of author's economic rights to ERGO software. The purchase of the above company allowed the Group to expand its portfolio of IT products for the public sector, as Geopolis was a company dedicated to supporting IT in public administration units (comarch.pl).
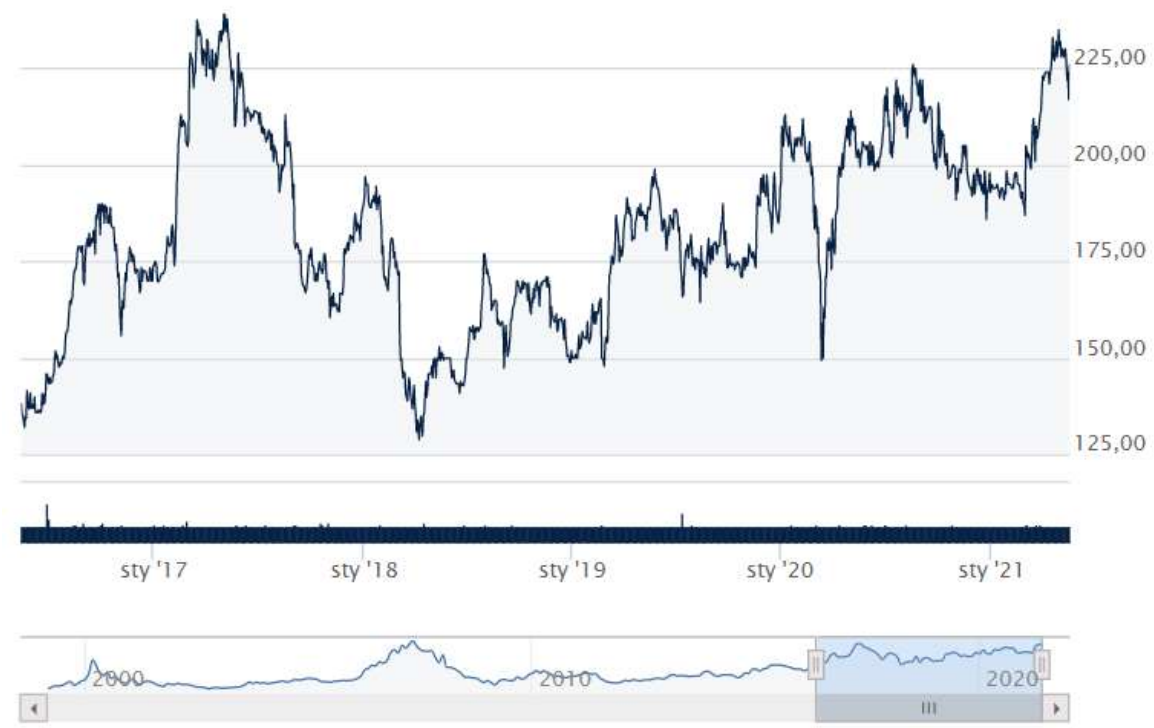

Figure 2. Quotes of Comarch on the Warsaw Stock Exchange in the period 2017-2021

Source: (bankier.pl/inwestowanie/profile/quote.html?symbol=COMARCH).

Figure 2 shows Comarch's stock price on the Warsaw Stock Exchange over the period 2017-2021. As in the case of Asseco Poland, Comarch's stock price was lowest at the turn of 2018 and 2019. The lowest price recorded over the presented 5 years was recorded on 6 June 2018 and amounted to 127.5000 PLN, while the highest price was 244.9000 PLN and was recorded on 4 May 2017.

The data presented in Figure 3 shows that the WIG-Informatyka index is dominated by the Asseco Group companies (bankier.pl). Asseco Poland holds a 38\% equity interest, which confirms its dominant position in the index. Further members of the Asseco group are ASSECO SEE with $10 \%$ and ASSECOBS with $6 \%$. The second largest company in the above-mentioned index is Livechat with $18 \%$ share. Further positions are occupied by Comarch (11\%) and Datawalk (7\%), respectively. Other IT companies together have a 10\% share. 


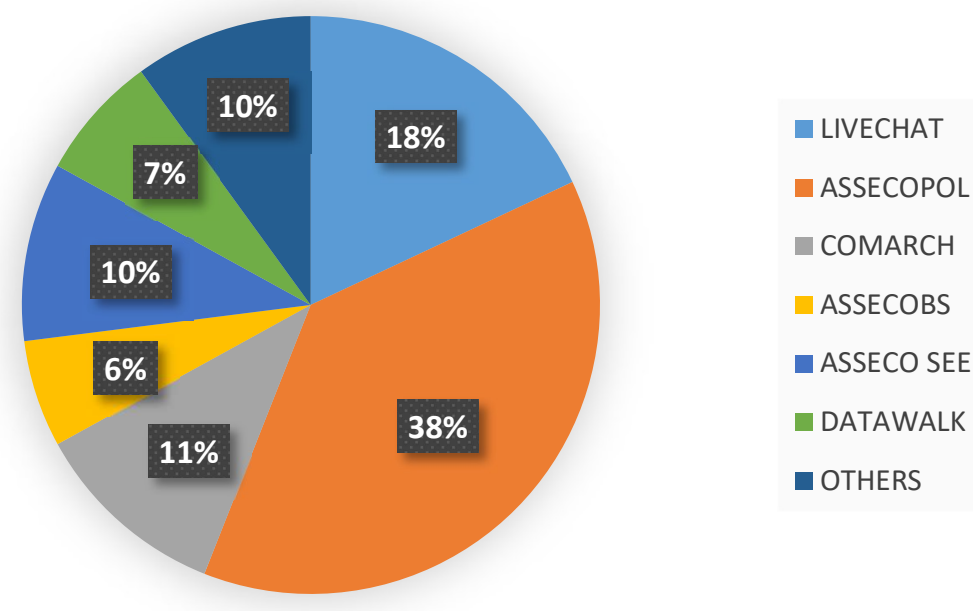

Figure 3. Shares of companies in the WIG-Informatyka index

Source: Own elaboration based on: (stockwatch.pl/gpw/indeks/wig-info,sklad.aspx).

\section{AN ANALYSIS OF COMPANIES ON THE BASIS OF SELECTED}

\section{FINANCIAL INDICATORS}

The ratio analysis of Asseco Poland and Comarch has been carried out based on the data from financial statements (Gartner Report). and the data presented by the companies in their regulatory filings. Tables 1 and 2 present main indicators of companies studied.

Table 1. Profitability ratios for Asseco Poland

\begin{tabular}{|c|c|c|c|}
\hline & 2017 & 2018 & 2019 \\
\hline ROA & $3,19 \%$ & $3,13 \%$ & $3,95 \%$ \\
\hline ROE & $3,49 \%$ & $3,36 \%$ & $4,23 \%$ \\
\hline ROS & $13,89 \%$ & $20,12 \%$ & $13,46 \%$ \\
\hline ROI & $174,11 \%$ & $9,75 \%$ & $30,71 \%$ \\
\hline
\end{tabular}

Source: Own elaboration based on data from the 2017-2019 financial statements of Asseco Poland.

Table 2. Profitability ratios for Comarch

\begin{tabular}{|c|c|c|c|}
\hline & 2017 & 2018 & 2019 \\
\hline ROA & $3,15 \%$ & $3,72 \%$ & $4,13 \%$ \\
\hline ROE & $4,94 \%$ & $5,95 \%$ & $6,54 \%$ \\
\hline ROS & $7,02 \%$ & $12,25 \%$ & $4,33 \%$ \\
\hline ROI & $37,16 \%$ & $45,05 \%$ & $45,25 \%$ \\
\hline
\end{tabular}

Source: Own elaboration based on data from the 2017-2019 financial statements of Comarch. 
A first "bird's eye" look at the two basic analytical ratios ROA and ROE (Nowak, 2008) in the surveyed companies shows that return on assets and return on equity show a higher growth rate in Comarch than in Asseco Poland. Although ROA in 2017 in Asseco is higher than in Comarch, in the following years the value of this indicator grows faster in the case of Comarch than in Asseco. However, the absolute values of these ratios, except for 2018, are at similar levels (Figure 4) (Gołębiowski, 2016; Babalola, Abiola, 2013).

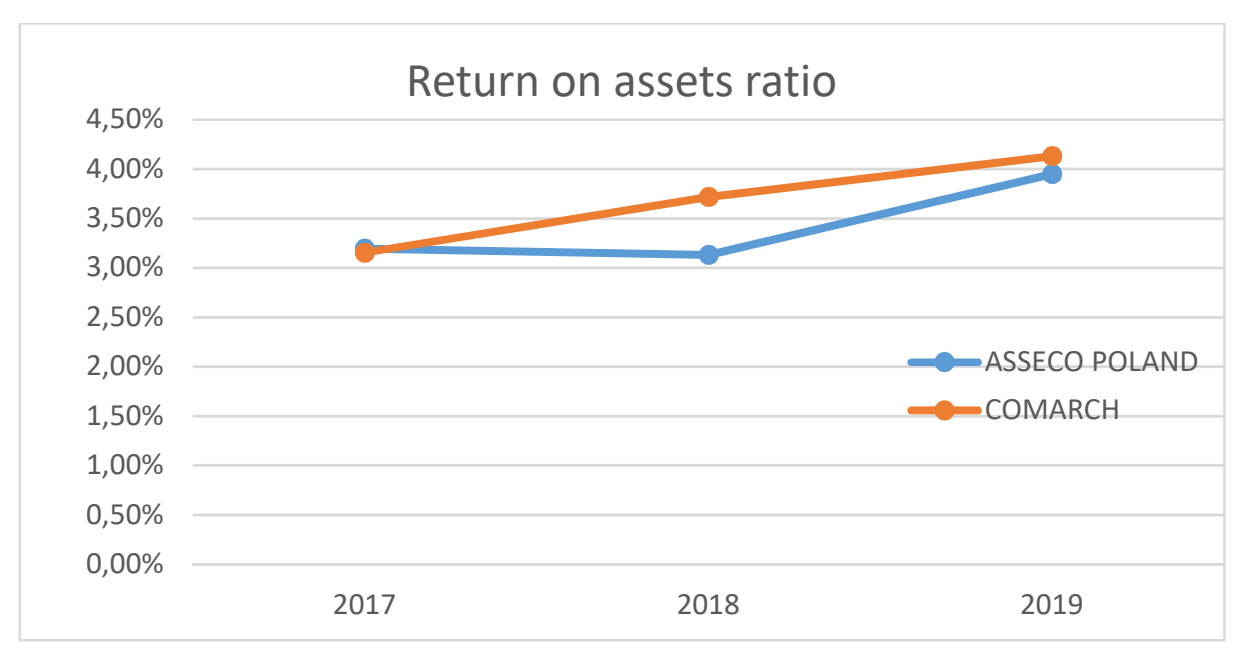

Figure 4. Comparison of return on assets ratios

Source: own elaboration based on financial statements of Asseco Poland and Comarch for 2017-2019.

Asseco Poland's return on assets ratio shows that in 2017, one PLN of assets managed to generate 0.0319 PLN of profit, against 0.0315 PLN for Comarch. A year later, the difference in the level of indicators was 0.0059 PLN in favor of Comarch and in 2019 this difference has minimized to 0.0018 PLN. The increase in the value of this ratio in Asseco in the last analyzed year was influenced by the steady growth of net profit from PLN 175 million in 2017 to over PLN 200 million in 2019 (Bednarski, 2007).

The return on equity (Figure 5) was higher in Comarch in each of the years under analysis. Both the above-mentioned companies are characterized by a growing trend, but the growth dynamics is also higher in Comarch (1.32\%) than in Asseco (1.21\%) (Bien, 2005).

On the other hand, when analyzing the profitability of sales (Waśniewski, Skoczylas, 2002), one can clearly see the advantage of Asseco. In the analyzed years, the Podkarpackiebased company managed to generate the average return on sales at the level of $15.82 \%$, which means that each PLN of realized sales brought the company almost 0.16 PLN of net profit (Figure 6) (Brigham, Houston, 2013). In the competing company in Cracow, the return on sales ratio was on average at the level of $7.87 \%$, i.e. the company was able to generate profit per 1 PLN of sales - at the level of ca. 0.08 PLN. This may prove that the Rzeszów company is much more focused on maximally beneficial conclusion of sales transactions. It has an impact on the increase of the profit sum and, as a result, on the increase of the company's equity and capital position (De Franco, Kothari, Verdi, 2011). 


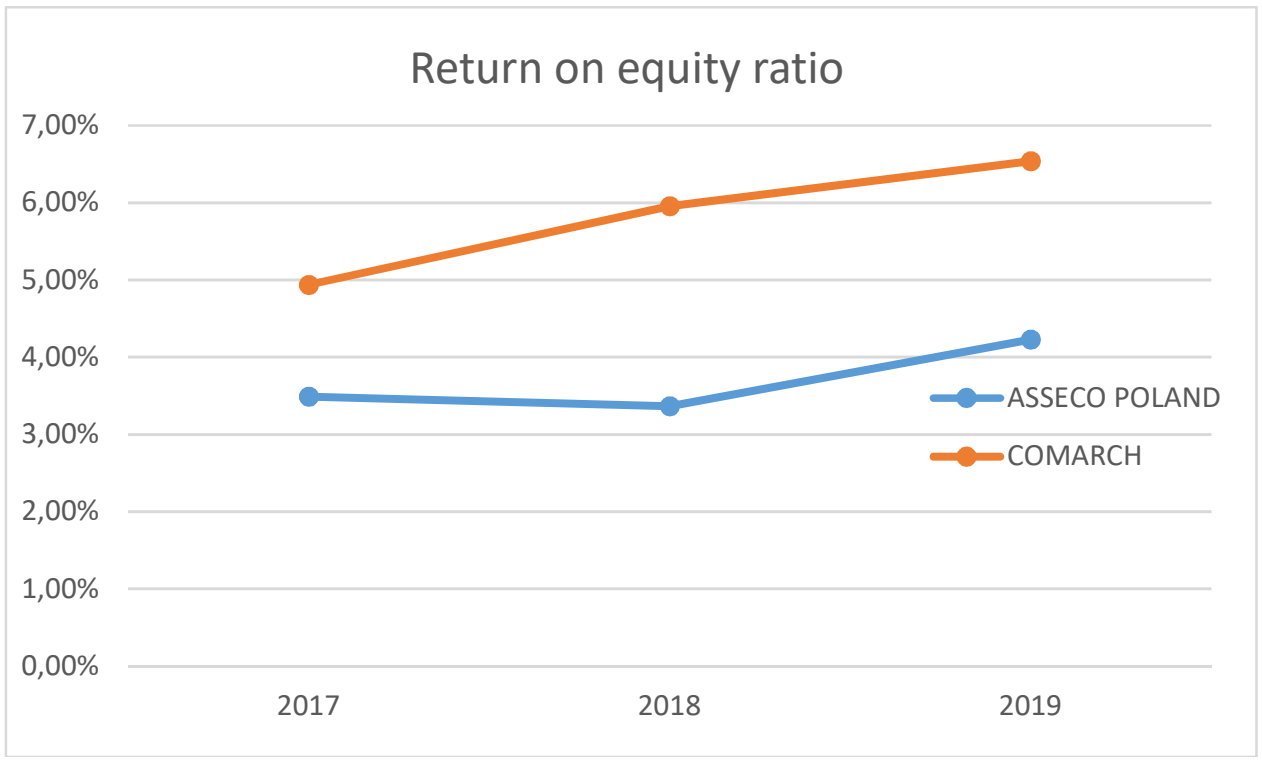

Figure 5. Comparison of return on equity ratios

Source: own elaboration based on financial statements of Asseco Poland and Comarch for 2017-2019.

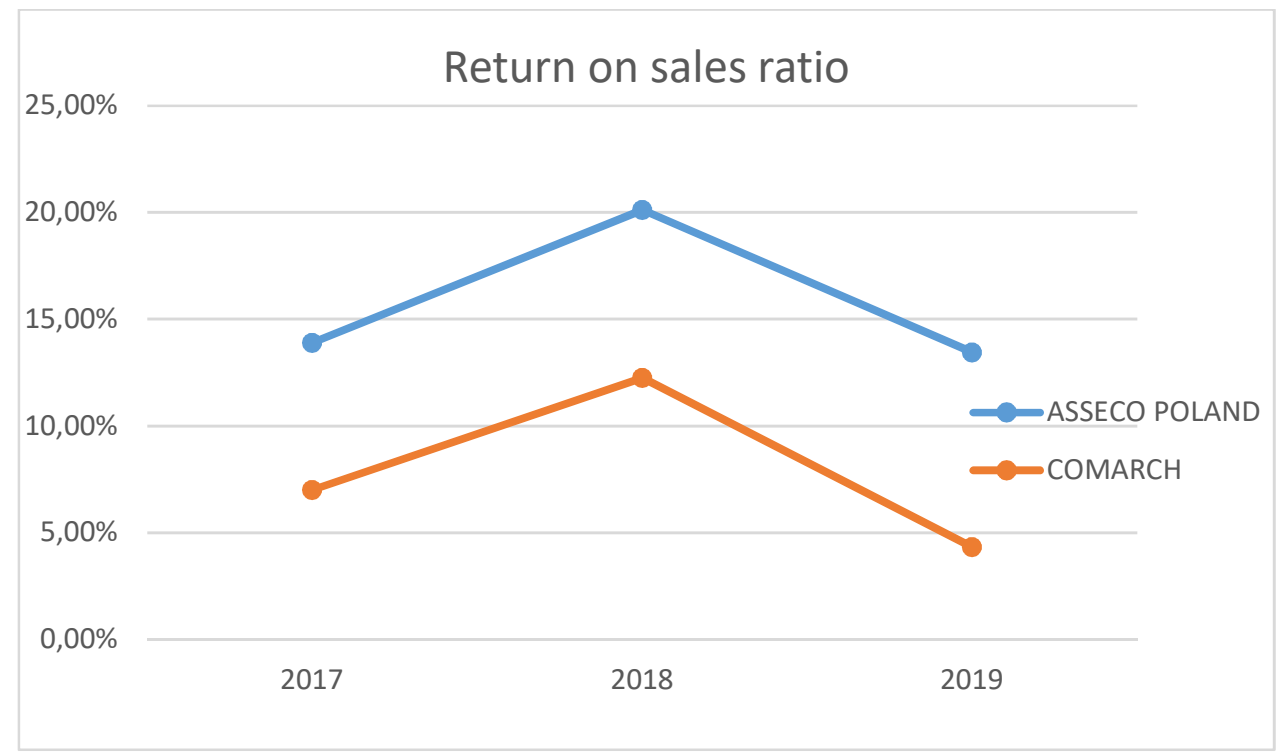

Figure 6. Comparison of return on sales ratios

Source: own elaboration based on financial statements of Asseco Poland and Comarch for 2017-2019. 


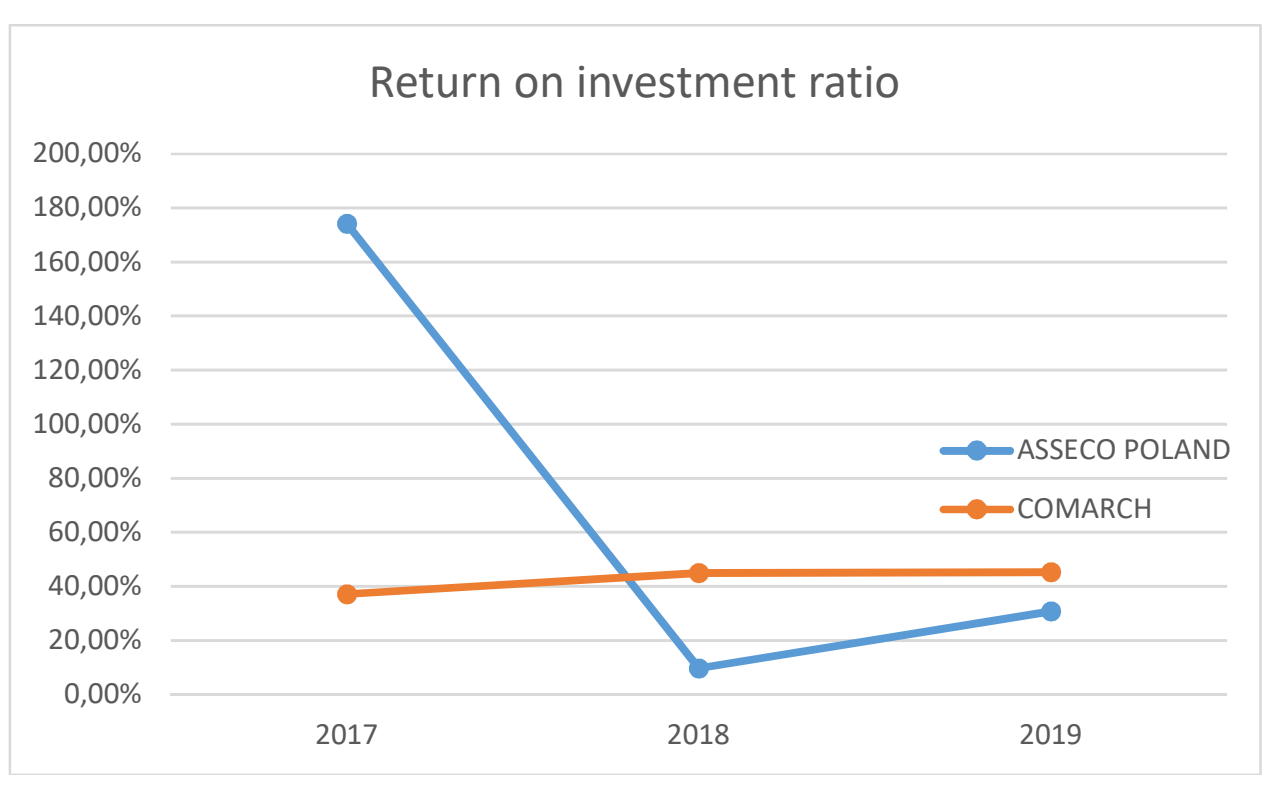

Figure 7. Comparison return on investment ratios

Source: own elaboration based on financial statements of Asseco Poland and Comarch for 2017-2019.

The return on investment ratio shows how profitable the investments (Vance, 2003) were over the analyzed years in the companies under analysis, that is, it informs how many PLN of profit one PLN invested allowed to generate. ROI indicator shows that in the first examined year Asseco showed much higher profitability of investment than Comarch (Gabrusewicz, 2005). Asseco realized the indicator at a very high level of $174 \%$, which is due not to the huge profit but to the spending of small capital expenditures in that year, which (as the data in Figure 7 shows) were realized in the following year causing the indicator to drop to $9.75 \%$. In 2017 , the ROI was as high as $174.11 \%$, influenced by the amount of cash invested in the amount of over 400 million. In that year, the company intensively expanded in foreign markets, which resulted in the achievement of $80 \%$ of sales. The Asseco Group also managed to effectively execute new acquisitions. Very important for Asseco were revenues from sales of proprietary software and services (Tokarski, Tokarski, Mosionek-Schweda, 2017; Lew, 2016; Lew et al., 2017), which amounted to PLN 6.2 billion (asseco.com) in $2017^{3}$. And in 2019, this ratio returned to $30.71 \%$, which is lower than Comarch's ratio of $45.35 \%$ this year (asseco.pl; Financial statements of Asseco Poland).

Since 2017 it is Comarch that presents a stable value of the above indicator, in 2017 $37.16 \%$, in $2018-45.05 \%$. It should be noted that the values of ROI in Comarch do not vary as much as in the case of Asseco, which may indicate a stable, more cautious investment policy.

\footnotetext{
${ }^{3}$ Data derived from the consolidated financial statements of Asseco Poland for 2017.
} 


\section{ASSET STRUCTURES}

The structure of current assets indicates a good financial and economic situation in both companies. On a positive note, the current assets of Comarch are increasing. An analysis of the current assets structure indicates that Asseco is in better shape. The company from Rzeszów holds much less inventory, and has more cash than Comarch. Asseco's cash stood at over 150,000 PLN in each of the years under review, and its share in current assets exceeded 35\% (Report of the Management...). In turn, Comarch holds ca. 70 thousand in cash and its share in current assets is lower than in Asseco Poland (Campello et al., 2011). Asseco Poland holds much more fixed assets, while the share of current assets decreases. The asset structure of Asseco Poland should be assessed negatively because fixed assets constitute a substantial majority of its total assets. Their number, and at the same time their percentage share in total assets, increased over the analyzed years to over $91 \%$. The value of fixed assets increased, accompanied by a downward trend in the amount of current assets. From the point of view of financial liquidity, fixed assets should constitute a smaller part or half of all assets, as it is more difficult to convert them into cash to repay the debt (Cornett et al., 2011; Disatnik, 2013). Both, the structure of liabilities and assets indicates that Asseco is developing more dynamically. The amount of assets held, including fixed assets, may indicate an aggressive development strategy of the company (Kreczmańska-Gigol, 2015; Lew et al., 2021) and in a long-term perspective building strong foundations of own fixed assets may be a promising development advantage for the Rzeszów-based company. This results from the adopted policy of building fixed assets and investing in modern and efficient hardware (analizy-prognozy.pl). In Comarch, it is noticeable that the value of current and non-current assets is at a similar level. An analysis of the structure of current assets shows that Comarch has managed to reduce the share of inventories in current assets (Comarch S.A. financial statements).

\section{STRUCTURE OF LIABILITIES}

An analysis of the structure of liabilities indicates (Table 3) that in the analyzed period Asseco Poland financed its operations mostly with short-term credits. This is evidenced by the amount of short-term liabilities held and their share in total liabilities (Wypych, 2007). The number of short-term liabilities has been decreasing over the years - from over 278 thousand to less than 210 thousand. Together with the decreasing value of current liabilities, the number of long-term liabilities is also decreasing. It can be concluded that the company is financing its activities with the use of foreign capital to an increasingly smaller extent (Gąsiorkiewicz, 2011; Gibson, 2011).

This is because equity is a method of financing that does not incur financial expenses and Asseco Poland held equity of approximately PLN 5 million in 2017-2019. Over the analyzed years, we can see an increase in the share of equity in total liabilities, although the amount of equity is decreasing with a downward trend in the amount of debt capital (finanse21.pl). In Asseco Poland this percentage is higher than $90 \%$ in each of the analyzed years. In the nearest future the company should have no problems with maintaining its development strategy and keeping its liquidity (Gołębiowski, Taczała, 2005). 
Table 3. Liabilities structure ratios of Asseco Poland SA

\begin{tabular}{|l|c|c|c|c|c|c|}
\hline \multirow{2}{*}{} & \multicolumn{2}{|c|}{2017} & \multicolumn{2}{c|}{2018} & \multicolumn{2}{c|}{2019} \\
\cline { 2 - 7 } & $\begin{array}{c}\text { In thousand } \\
\text { PLN }\end{array}$ & In \% & $\begin{array}{c}\text { In thousand } \\
\text { PLN }\end{array}$ & In \% & $\begin{array}{c}\text { In thousand } \\
\text { PLN }\end{array}$ & In \% \\
\cline { 2 - 7 } & \multicolumn{5}{|c|}{ Liabilities structure ratios } \\
\hline $\begin{array}{l}\text { Long-term } \\
\text { liabilities }\end{array}$ & 183,8 & $3,3 \%$ & 140,4 & $2,6 \%$ & 137,2 & $2,6 \%$ \\
\hline $\begin{array}{l}\text { Short-term } \\
\text { liabilities }\end{array}$ & 278,5 & $5,1 \%$ & 226,7 & $4,3 \%$ & 206,1 & $3,9 \%$ \\
\hline Equity & 5035,7 & $91,6 \%$ & 4949,8 & $93,1 \%$ & 4892,4 & $93,4 \%$ \\
\hline $\begin{array}{l}\text { Total } \\
\text { liabilities }\end{array}$ & 5498,0 & $100 \%$ & 5316,9 & $100 \%$ & 5235,7 & $100 \%$ \\
\hline
\end{tabular}

Source: own elaboration based on Asseco Poland's 2017-2019 financial statements.

Comarch is characterized by a similar amount of long-term and short-term liabilities (Table 4). The share of current liabilities is higher than that of long-term liabilities, but their value is not high (Grzenkowicz et al., 2017). A positive aspect here is also the amount of equity, which increases with each passing year. The percentage share of equity since 2017 has remained at a comparable level of $72-75 \%$ with a steadily increasing level of equity in the following years 2017-2019. Despite the increasing equity, its share in total liabilities shows a trend of a constant relationship.

Table 4. Comarch SA liabilities structure

\begin{tabular}{|l|c|c|c|c|c|c|}
\hline & \multicolumn{2}{|c|}{2017} & \multicolumn{2}{c|}{2018} & \multicolumn{2}{c|}{2019} \\
\cline { 2 - 7 } & $\begin{array}{c}\text { In thousand } \\
\text { PLN }\end{array}$ & In \% & $\begin{array}{c}\text { In thousand } \\
\text { PLN }\end{array}$ & In \% & $\begin{array}{c}\text { In thousand } \\
\text { PLN }\end{array}$ & In \% \\
\cline { 2 - 7 } & \multicolumn{5}{|c|}{ Liabilities structure ratios } \\
\hline $\begin{array}{l}\text { Long-term } \\
\text { liabilities }\end{array}$ & 154,8 & $14 \%$ & 120,9 & $10,9 \%$ & 152,3 & $12,7 \%$ \\
\hline $\begin{array}{l}\text { Short-term } \\
\text { liabilities }\end{array}$ & 155,2 & $14 \%$ & 157,1 & $14,1 \%$ & 160,9 & $13,5 \%$ \\
\hline Equity & 797,0 & $72 \%$ & 834,2 & $75 \%$ & 881,5 & $73,8 \%$ \\
\hline $\begin{array}{l}\text { Total } \\
\text { liabilities }\end{array}$ & 1107,0 & $100 \%$ & 1112,2 & $100 \%$ & 1194,7 & $100 \%$ \\
\hline
\end{tabular}

Source: own compilation based on Comarch S.A.'s 2017-2019 financial statements.

Both Comarch and Asseco Poland are in a good position in terms of the structure of their liabilities (Hamrol, 2013; Kowalak, 2011). Neither company is at risk of financial insolvency, as they have sufficient cash to settle their liabilities in due time. Moreover, both companies do not have too much debt capital. In the Authors' opinion, Asseco is in a slightly better position because it has much higher equity as well as the ability to obtain external capital and external sources of financing (Kowalska, 2013; Lee, 2009). 


\section{FINANCIAL POSITION OF ASSECO POLAND IN THE PANDEMIC PERIOD}

In March 2020, a coronavirus pandemic was announced globally, which also affected the Polish economy. With the Polish government announcing a lockdown, Asseco Poland decided to work remotely. The company's authorities initially expected that there might be delays in the implementation of projects whose initial phases were to start in Q1 or Q2 $2020^{4}$.

In its most recent financial statements, Asseco's Management Board assessed that the company's operations are not threatened, and that the company will not face any difficulties in meeting its orders or obligations for 12 months starting from 31 December 2020 until the end of 2021 (Kłos, 2021). Asseco Poland achieved satisfactory results after impairment testing of its assets due to the prevailing pandemic. No substantial risk of impairment of assets, including primarily goodwill, was identified. Furthermore, the statements show no significant change in the collection of receivables, which positively influences the calculation of expected losses on trade credits granted to business partners. Analyzing the reports published in 2021, it should be pointed out that the pandemic did not exert a significant influence on the company's operations. This is confirmed by the fact that Asseco Poland did not make a decision on taking advantage of the "anti-crisis shield" and the offered funds from PFR, nor did it apply for changing the dates of tax payments or make any adjustments to its leasing contracts ${ }^{5}$ (wnp.pl).

The evidence indicating the company's dynamic exit from the pandemic period is the new project that the company has started to implement together with the National Cloud Operator. This project concerns the creation of a special purpose company called the National Medical Cloud Operator, in which the founding companies each have a $50 \%$ stake. The entity is tasked with implementing electronic medical records (EMR) in the cloud. It is to serve medical laboratories from April 2021, outpatient clinics and medical practices from May 2021, and hospitals from the second half of the year. A separate division of the company for this purpose will operate on the Google Cloud platform (bankier.pl).

Asseco has not noticed any significant changes in its financial results due to the crisis, but does not rule out that some negative effects may appear in the future. At the gala organized by Dziennik Gazeta Prawna, entitled "There is no future without entrepreneurship", President of Asseco Poland Adam Góral pointed out that he is concerned about the psychological condition of his employees, which has been affected by long-term remote work (Goral, 2021). He stressed that many of them are introverts and working in a team where they had contact with each other was certainly much more comfortable for them (Berenda, 2021).

In recent years, we can see the progressive process of globalization, which affects the increase in the level of competitiveness, as well as providing continuous technological development in the field of hardware, software, IT systems. These factors make the current conditions of doing business different from what it was a few years ago. Now the most important feature that an enterprise must meet in order to successfully run its business is the ability to quickly adapt to market conditions (Pomykalska, Pomykalski, 2017). For both large and smaller companies it is crucial to have IT solutions (itwiz.pl). IT has become an important part of the corporate architecture, as business units in order to improve the

\footnotetext{
${ }^{4}$ Financial statements of Asseco Poland S.A. for the year 2019.

${ }^{5}$ Unofficial financial statements of Asseco Poland S.A. for the year 2020.
} 
efficiency and effectiveness of business processes implement packages of IT systems (Misztal, 2018).

From 2012 until the outbreak of the pandemic, the IT market worldwide grew at an average annual rate of $3.4 \%$, with the fastest growth characterized by sales of enterprise software (statista.com). The pandemic caused the IT market to develop at a much faster pace. It is indicated by quotations of the WIG-Informatyka index at the Warsaw Stock Exchange.

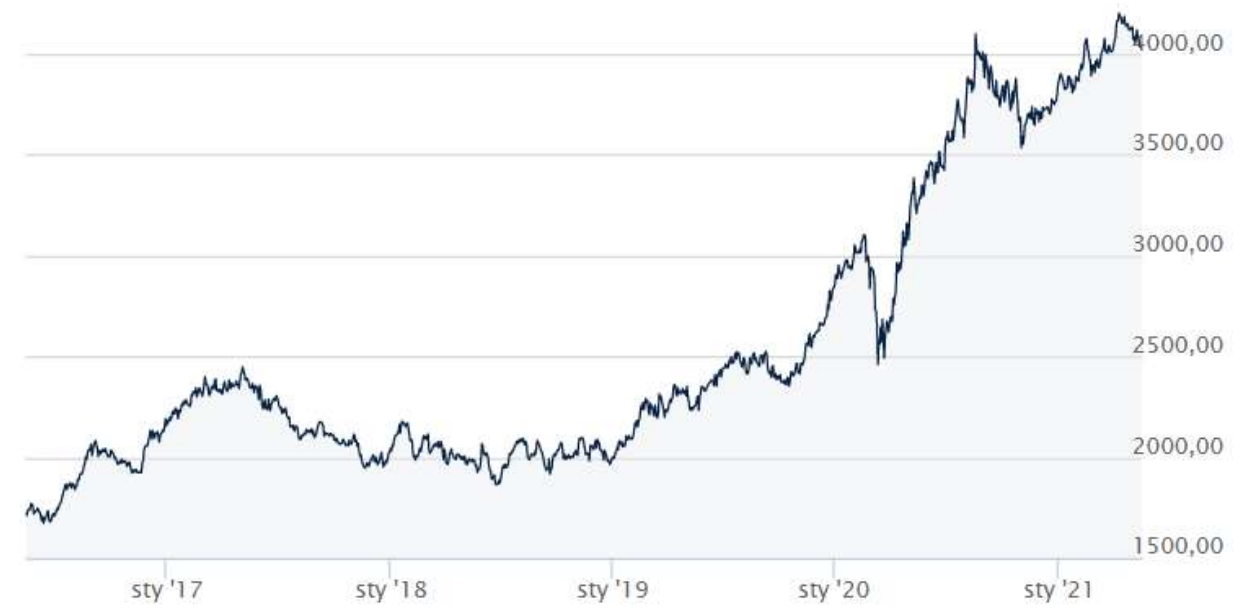

Figure 8. WIG-INFORMATYKA index portfolio over the period 2017-2021

Source: (www.bankier.pl/inwestowanie/profile/quote.html?symbol=WIG-INFO).

Figure 8 presents the quotations of the WIG-INFORMATYKA index on the Warsaw Stock Exchange over the period 2017-2021 (t) (e). It can be observed that the IT market has been in a bull market since January 2020. This allows us to conclude that the crisis caused by the COVID-19 pandemic did not affect the IT industry, but on the contrary, caused its development. In March 2020, the index price fell due to the announcement of the first lockdown in Poland, as it forced all companies to switch to remote working. However, since then the share price of IT companies has been increasing at a dynamic pace. The year 2020 showed that the global IT market was the least affected by the pandemic crisis. Predictions for future years are equally optimistic. Gartner predicts that global corporate spending on information technology in 2021 will increase by $6.2 \%$ compared to last year and will reach 3.9 trillion dollars (Gartner Report). Analysts are predicting particular growth in the software market, with forecasts indicating that enterprise software spending will grow $8.8 \%$ ( $\$ 506$ billion) in 2021, up from a $2.4 \%$ decline last year. The growth rate is expected to be even stronger in 2022, when enterprise software spending will grow $10.2 \%$ to reach $\$ 557$ billion (marketingcharts.com). 
Forecasts of the domestic IT market were also presented in a report prepared by Bank Pekao SA. Analysts emphasize in the report that the IT industry in Poland is characterized by relative immunity to the pandemic crisis. The authors of the report point out to the fact that the income dynamics was slowed down by almost a half, but they also point out to the fact that the industry recorded the smallest drops (Pekao Report).

Analysts of the report also point to opportunities for the development of the IT industry in Poland, such as: digital transformation of the economy, companies and citizens, caused and driven by the crisis, the fact of low saturation of IT services in the country, as well as, the emergence of new products and IT services that enable new opportunities for development and create market niches. The authors of the report consider the most important feature that enables the development of the industry to be the competitive advantages such as: high competence of the staff and organizational advantages while maintaining low costs (Sierpińska, Jachna, 2004; rp.pl; analizy-prognozy.pl).

The crisis caused by the pandemic significantly accelerated the progress of digital infrastructure. Specialists believe that if it were not for the pandemic, these changes would take much longer, even several years. Analysts predict a further increase in the pace of development and emphasize that the most dynamic development will be cloud infrastructure (u). They predict that by the end of $2021-80 \%$ of organizations will implement a mechanism to move to infrastructure and applications that are based on the cloud, at a rate twice as fast as they would have done without the crisis (idc.com).

To sum up, all the analysts agree that the IT industry is going to develop at an even faster pace. Taking into account the above-mentioned predictions as well as the financial results of Asseco Poland, we may conclude that the company will develop more and more dynamically, and thus generate higher and higher revenues (money.pl; computerworld.pl). The Group plans to incorporate other companies which will enable it to widen its customer base and expand its business worldwide (pl.asseco.com; rzeszowskieinfo.pl).

Asseco Poland is able to grow steadily, which was proved by the company's financial results during the pandemic. An industry-based study has shown that Asseco Poland is the largest Polish company selling software (biznesistyl.pl). E-learning training software to be used in high schools and universities such as eduPortal PRz used at Rzeszow University of Technology proved to be very useful during the pandemic. At present the Company has the largest market share in the WIG-INFORMATYKA stock exchange index; the results of economic and financial analysis carried out in this material suggest that there is a good chance Asseco Poland SA will maintain this position in the future.

\section{CONCLUSION}

Based on the conducted research on business activities and strategies of operations during the crisis caused by COVID-19 and achieved financial results, it can be concluded that both studied IT corporations Asseco Poland SA and Comarch SA were very involved in offering solutions to the IT market for application of software and online communication platforms in the Polish economy. This contributed to acceleration of the crisis-driven digital transformation of the economy, companies, offices, schools and universities. The most important features that enabled the development and good results of these companies can also be considered high competence of the staff and organizational advantages while maintaining low costs (Xu et al., 2014). Asseco demonstrated more stable financial 
standing. This is manifested by strengthening of the capital position and active expansion into foreign markets.

Taking into account the achieved financial results, structure of assets and liabilities as well as forecasts for development of IT companies in Poland, one may conclude that Asseco Poland will develop more dynamically and earn higher revenues. The Asseco Group plans to incorporate other companies into its operations in order to extend the customer network and expand its business worldwide.

\section{REFERENCES}

Babalola, Y.A., Abiola, F. R. (3013). Financial Ratio Analysis of Firms: A Tool for Decision Making. "International Journal of Management Sciences", Vol. 1, No. 4.

Bednarski, L. (2007). Analiza finansowa w przedsiębiorstwie. Warsaw: PWE.

Berenda, K., No future without entrepreneurship [Access: 10.04.2021]. Access on the internet: https://forsal.pl/biznes/aktualnosci/wideo/7844831, goral-konkurencja-to-jest-gra-jesliwykorzystamy-covid-19-by-sie-tlumaczyc-to-przegramy.html

Białas, K. (2017). Rola dynamicznych wskaźników plynności finansowej w zarządzaniu przedsiębiorstwem. „Finanse i Prawo Finansowe”, Vol. 4, No. 1.

Bień, W. (2005). Zarządzanie finansami przedsiębiorstwa. Warsaw: Difin.

Brigham, E. F., Houston, J. F. (2013). Fundamentals of Financial Management. Boston: Cengage Learning.

Campello, M., Giambona, E., Graham, J. R., Harvey, C. R. (2011). Liquidity management and corporate investment during a financial crisis. "The review of financial studies", Vol. 24, issue 6.

Comarch S.A. financial statements for 2017, 2018, 2019

Cornett, M. M., McNutt, J. J., Strahan, P. E., Tehranian, H. (2011). Liquidity risk management in credit supply in the financial crisis. "Journal of Financial Economics", Vol. 101, issue 2.

De Franco, G., Kothari, S., Verdi, R. S. (2011). The Benefits of Financial Statement Comparability. "Journal of Accounting Research", 49, March.

Disatnik, D., Duchin, R. Schmidt, B. (2013). Cash flow hedging and liquidity choices. "Review of Finance", 18(2).

Financial statements of Asseco Poland S.A. for 2017, 2018, 2019.

Gabrusewicz, W. (2005). Podstawy analizy finansowej. Warsaw: PWE.

Gartner Report: www.statista.com/statistics/722765/worldwide-gartner-annual-revenue

Gąsiorkiewicz, L. (2011). Analiza ekonomiczno-finansowa przedsiębiorstw. Warsaw: Oficyna Wydawnicza Politechniki Warszawskiej.

Gibson, C. H. (2011). Financial reporting and analysis. Using Financial Accounting Information. Boston: Cengage Learning.

Gołębiowski, G., ed. (2016). Analiza finansowa przedsiębiorstwa. Warsaw: Difin.

Gołębiowski, G., Taczała A. (2005). Analiza ekonomiczno-finansowa w ujęciu praktycznym. Warsaw: Difin.

Góral, A., (2021), Speech at the gala "There is no future without entrepreneurship" [Access: 10.04.2021]. Access on the internet: https://forsal.pl/biznes/aktualnosci/wideo/7844831, goral-konkurencja-to-jest-gra-jesli-wykorzystamy-covid-19-by-sie-tlumaczyc-toprzegramy.html 
Grzenkowicz, N., Kowalczyk, J., Kusak, A., Podgórski, Z. (2017). Analiza finansowo ekonomiczna jako narzędzie oceny kondycji przedsiębiorstwa, Warsaw: wydawnictwo naukowe Wydziału Zarządzania Uniwersytetu Warszawskiego.

Hamrol, M. (2013). Niedoceniane aspekty badania sprawozdania finansowego przedsiębiorstwa. ,Zeszyty Naukowe Uniwersytetu Szczecińskiego”, nr 760.

Kłos, M. (2021). Analiza wskaźnikowa przedsiębiorstwa dla potrzeb kredytowych banku na przykładzie Asseco Poland. Master's thesis. Rzeszów: University of Rzeszów.

Kowalak, R. (2011). Syntetyczny miernik oceny kondycji finansowej przedsiębiorstwa. „Zeszyty Naukowe Uniwersytetu Szczecińskiego", nr 668.

Kowalska, S. (2013). Znaczenie płynności finansowej $w$ zarządzaniu przedsiębiorstwem w sytuacjach kryzysowych. ,Zeszyty Naukowe Uniwersytetu Szczecińskiego”, nr 757.

Kreczmańska-Gigol, K. (2015.) Pomiar płynności finansowej [w:] Plynność finansowa przedsiębiorstwa. Warsaw: Difin.

Lee, A. C., Lee, J. C., Cheng, F. (2009). Financial Analysis, Planning \& Forecasting: Theory and Application. London: World Scientific Publishing.

Lew, G. (2016). Ogólny model rachunku kosztów klienta. "Humanities and Social Sciences", Vol. XXI (April-June - 2/2016).

Lew, G., Nieplowicz, M., Ossowski, M., Zackiewicz-Brunke, B. (2021). Zrównoważona karta wyników $w$ praktyce polskich przedsiębiorstw i instytucji. Katowice: Instytut Prawa Gospodarczego.

Lew, G., Pacana, A., Kulpa, W. (2017). The concept of customer cost accounting. "Journal of Business and Retail Management Research", 11/3, April.

Misztal, A. (2018). Funkcjonowanie e-biznesu. Łódź: Wydawnictwo Uniwersytetu Łódzkiego.

Nowak, E. (2008). Analiza sprawozdań finansowych. Warsaw: PWE.

Pekao Report: https://www.rp.pl/Banki/301049904-Bariery-i-szanse-dla-polskiego-sektora-ITw-2021-r.html

Pomykalska, B., Pomykalski, P. (2017). Analiza finansowa przedsiębiorstwa. Wskaźniki i decyzje w zarzadzaniu. Warsaw: PWN.

Report of the Management Board on business operations of the Asseco Group and Asseco Poland S.A. for 2019.

Sierpińska, M., Jachna T. (2004). Ocena przedsiębiorstwa wedtug standardów świata, PWN, Warsaw.

Tokarski, A., Tokarski, M., Mosionek-Schweda, M. (2017). Pomiar i ocena płynności finansowej podmiotu gospodarczego. Warsaw: CeDeWu.

Vance, E. E. (2003). Financial Analysis and Decision Making. New York: McGraw-Hill.

Waśniewski, T., Skoczylas, W. (2002). Teoria i praktyka analizy finansowej $w$ przedsiębiorstwie. Warsaw: Fundacja Rozwoju Rachunkowości w Polsce.

Wypych, M., ed. (2007). Finanse przedsiębiorstwa z elementami zarządzania i analizy. Łódź: ABSOLWENT.

Xu, W., Xiao, Z., Dang, X., Yang, D., Yang, X. (2014). Financial ratio selection for business failure prediction using soft set theory. "Knowledge-Based Systems", Vol. 63.

https://analizafinansowa.pl/analiza-wskaznikowa/analiza-zadluzenia-firmy-4253.html https://analizy-prognozy.pl/analiza-prognoza-finansowa/analiza/wskaznikowa/zadluzenia/ wyplacalnosc/ 
https://analizy-prognozy.pl/analiza-prognoza-finansowa/analiza/wskaznikowa/plynnoscifinansowej/plynnosci-dynamicznej/

https://brandsit.pl/badanie-branza-it-w-polsce-w-2020-roku/

https://itwiz.pl/najwieksze-firmy-polsce-roku-2019-ranking-itwiz-best100/

https://pl.asseco.com/aktualnosci/asseco-international-zajmie-sie-miedzynarodowymrozwojem-grupy-asseco-2614/

https://pl.asseco.com/aktualnosci/asseco-otwiera-nowy-dzial-rd-3058/

https://pl.asseco.com/aktualnosci/asseco-poland-wchodzi-na-nowe-rynki-w-afryce-i-inwestujew-portugalii-24/

https://pl.asseco.com/aktualnosci/rynki-zagraniczne-motorem-rozwoju-grupy-asseco-w-2017roku-2771/

https://prnews.pl/comp-rzeszow-zmienil-nazwe-na-asseco-poland-71019

https://www.bankier.pl/inwestowanie/profile/quote.html?symbol=ASSECOPOL

https://www.bankier.pl/inwestowanie/profile/quote.html?symbol=COMARCH

https://www.bankier.pl/inwestowanie/profile/quote.html?symbol=WIG-INFO

https://www.bankier.pl/wiadomosc/Asseco-Poland-i-Chmura-Krajowa-utworzyly-KrajowegoOperatora-Chmury-Medycznej-8088546.html

https://www.biznesistyl.pl/biznes/biznes-na-co-dzien/52_asseco,-rzeszowska-firma-zglobalnymi-ambicjami.html

https://www.computerworld.pl/news/Comp-Rzeszow-przejal-ASSET-Soft,311627.html

https://www.computerworld.pl/news/Porzadkowanie-portfela-spolek-w-Grupie-Asseco, 409440.html

https://www.finanse21.pl/analiza-finansowa.html

https://www.idc.com/getdoc.jsp?containerId=US46942020

https://www.marketingcharts.com/industries/technology-116207

https://www.money.pl/gielda/wiadomosci/artykul/asseco-tworzy-asseco-enterprise-solutions-, 111,0,2222191.html

https://www.rp.pl/Banki/301049904-Bariery-i-szanse-dla-polskiego-sektora-IT-w-2021-r.html

https://www.rzeszowskieinfo.pl/asseco-wchodzi-na-rynek-filipinski/

https://www.statista.com/statistics/722765/worldwide-gartner-annual-revenue/

https://www.wnp.pl/tech/koronawirus-nie-dotknal-asseco,397247.html

DOI: $10.7862 /$ rz.2021.hss.30

The text was submitted to the editorial office: December 2019.

The text was accepted for publication: December 2021. 
